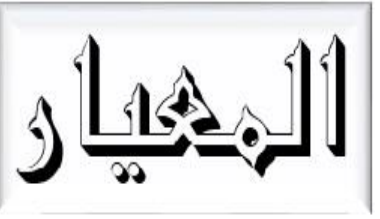

Al Mi'yar

Vol. 4, No. 2, Oktober 2021

P-ISSN: 2620-6749, E-ISSN: 2620-6536

DOI: $10.35931 / \mathrm{am} . v 4 \mathrm{i} 2.666$

\title{
PEMATUHAN MAKSIM KUANTITAS GRICE PADA TUTURAN GURU DALAM INTERAKSI KELAS BAHASA ARAB DI MA AL MUNAWAROH JOMBANG
}

\author{
Lailatul Qomariyah*1, Ahmad Sauqi Ahya², \\ UNHASY Tebuireng Jombang; Jawa Timur, Indonesia \\ STKIP PGRI Jombang, Jawa Timur, Indonesia
}

Email: *1lailatulqomariyah.unhasy@gmail.com,2ahmadsauqiahya84@yahoo.com

\begin{abstract}
The teacher's speech dominates in interactive activities with students in learning Arabic. To realize communicative and interactive learning, the teacher obeys the maxim of quantity proposed by Grice, which is to speak as briefly and clearly as possible so that the information conveyed can be understood easily. This article examines how to comply with Grice's maxim of quantity in the teacher's speech in Arabic class interaction. This research uses a qualitative case study approach in which data is collected through the documentation method and then analyzed using an interactive method. The results of this study are, the observance of the maxim of quantity in the teacher's speech is used in several categories; namely, 1) Requestives "begging", 2) Requestives "Praying"; 3) Requestives Ask; 4) Questions "ask"; 5) Questions "probing", and 6) Prohibitives "Prohibiting". Compliance with the maxim of quantity in Arabic classroom interactions between teachers and students positively impacts student activity and makes learning more conducive.
\end{abstract}

Keywords: the maxim of quantity, Speech act, classroom interaction.

\section{PENDAHULUAN}

Hafni dalam Asmadawati $^{1}$ menjelaskan bahwa keefektifan pembelajaran ditentukan oleh beberapa komponen yang saling mempengaruhi yakni, murid (الطالب), Kurikulum (المنهج الدراسي), Guru (المدرس), Metode (طريقة التندريس), Sarana pembelajaran (الوسائل التعليمية) dan Lingkungan (البيئة التعليمية). Dari beberapa komponen ini, guru paling

\footnotetext{
${ }^{1}$ Asmadawati, “Perencanaan Pengajaran,” Jurnal Darul 'Ilmi 02, no. 01 (2014): 1-13.
} 
mendominasi dalam keberhasilan proses interaksi pembelajaran di kelas. Adi $^{2}$, Hanifah ${ }^{3}$, Iqbal $^{4}$, dan Hikmah ${ }^{5}$ memiliki pendapat yang sama yakni guru harus mengembangkan kompetensinya karena dia memilki peran penting sebagai penentu keberhasilan aktivitas interaksi pembelajaran. Adi menambahkan bahwa aktivitas ini merupakan hubungan timbal balik antara guru dan murid dan setiap yang terlibat di dalam kegiatan tersebut berperan secara aktif melancarkan proses komunikasi.

Dalam pembelajaran Bahasa Arab, guru harus berkompeten dalam berinteraksi baik dengan siswa sehingga mampu menjadikan pembelajaran lebih efektif dan komunikatif. Kompetensi tersebut yakni kompetensi sosial. Dengan kompetensi ini, guru berkomunikasi sehingga mampu membangkitkan semangat siswa dalam mempelajari materi yang dipelajari dan memotivasi siswa untuk terlibat aktif untuk merespons dalam interaksi pembelajaran dan menjadikan proses belajar mengajar juga lebih berjalan baik. Hal ini sesuai dengan pendapat Anggun ${ }^{6}$, Suharsimi ${ }^{7}$, dan UndangUndang Republik Indonesia Nomor 14 pasal 10 bahwa guru harus memiliki

2 M Hasbi Ashsiddiqi, "Kompetensi Sosial Guru Dalam Pembelajaran Dan Pengembangannya," Ta'dib XVII, no. 14 (2012): 61-67. 61 dan 62

3 Umi Hanifah and Muhfidatul Winda Winda Hidayah, "Tathbîq Wasîlah Al-Ta'Lim 'Powtoon' Fî Tarqiyyati Mahōrah Al-Qirō'Ah," Al Mi'yar: Jurnal Ilmiah Pembelajaran Bahasa Arab Dan Kebahasaaraban 4, no. 1 (2021): 1, https://doi.org/10.35931/am.v4i1.362. Hlm. 5.

4 Muhammad Iqbal, "Penggunaan Metode Mim- Mem Untuk Mengembangkan Keterampilan Berbicara," Al Mi'yar: Jurnal Ilmiah Pembelajaran Bahasa Arab Dan Kebahasaaraban 1, no. 2 (2018): 113, https://doi.org/10.35931/am.v1i2.48. Hlm. 116.

${ }^{5}$ Nurul Hikmah, "Pembelajaran Kalam Dengan Media Musik (Lagu)," Al Mi'yar: Jurnal Ilmiah Pembelajaran Bahasa Arab Dan Kebahasaaraban 2, no. 1 (2019): 1, https://doi.org/10.35931/am.v2i1.98. hlm. 3

${ }^{6}$ Anggun Rahmawati and C Indah Nartani, "Kompetensi Sosial Guru Dalam Berkomunikasi Secara Efektif Dengan Siswa Melalui Kegiatan Pembelajaran Bahasa Indonesia Di SD Negeri Rejowinangun 3 Kotagede Yogyakarta," Trihayu: Jurnal Pendidikan Ke-SD-An 4, no. 3 (n.d.): 388-92.

7 Ashsiddiqi, "Kompetensi Sosial Guru Dalam Pembelajaran Dan Pengembangannya." hlm. 62 
kompetensi sosial yakni memiliki kemampuan baik dalam melakukan komunikasi dan interaksi dengan orang lain yang menjadi stakeholder di Sekolah untuk menciptakan atmosfir pembelajaran yang kondusif dan siswa terstimulasi untuk memberikan respons atas apa yang disampaikan oleh guru. Kompetensi ini dikatakan oleh Fauzi ${ }^{8}$ sebagai Kompetensi pengelolaan kelas. Gusti ${ }^{9}$ dan Sudirman (dalam Ridwan) ${ }^{10}$ dan Ina ${ }^{11}$ menambahkan bahwa kompetensi ini sangat dibutuhkan bagi guru sehingga perlu bagi guru untuk menentukan tujuan, langkah dan teknik penyampaian materi pembelajarannya serta medianya dalam berinteraksi dengan siswa. Media yang digunakan guru untuk berinteraksi yakni dengan tuturan atau tindak tutur. Evita ${ }^{12}$ dan Ulfah $^{13}$ sependapat bahwa kelancaran interaksi itu ditentukan oleh tindak tutur yang digunakan oleh penutur(guru) dan lawan tutur (siswa) yang berlatar belakang pengetahuan yang sama atas apa yang sedang dibicarakan pada kegiatan transfer ilmu.

Penggunaan tindak tutur yang tepat oleh guru akan berpengaruh positif dalam pembelajaran dan menjadikan pembelajaran lebih bermakna.

\footnotetext{
${ }^{8}$ Fauzi Miftakh Kelik Wachyudi, Mansyur Srisudarso, “Analisis Pengelolaan Dan Interaksi Kelas Dalam Pengajaran Bahasa Inggris,” Jurnal Ilmiah Solusi 1, no. 4 (n.d.): 40-49.

9 Gusti Ayu et al., "Analisis Interaksi Guru Dan Siswa Dalam Pembelajaran Bahasa Indonesia Di Kelas 1 SDN 1 Nawakerti," E Journal PGSD Universitas Pendidikan Ganesha 4, no. 1 (2016): 1-10.

10 Ridwan Nur Sineke Prasetio Rumondor, "Pola Interaksi Guru PAI Dengan Siswa Dalam Meningkatkan Hasil Belajar Di SMA Negeri 1 Belang," Al-Hikmah: Jurnal Pendidikan Dan Pendidikan Agama Islam 2, no. 2 (2020): 160-72.

11 Ety Nur Inah, "Peran Komunikasi Dalam Interaksi Guru Dan Siswa," Jurnal Al-Ta'dib 8, no. 2 (n.d.): 150-67.

12 Evita Sholeha Pra Yoga, "Tindak Perlokusi Dalam Percakapan Antarsiswa Kelas VII SMP Muhammadiyah Ahmad Dahlan Metro Tahun Pelajaran 2016/2017" (Universitas Lampung, 2017).

13 S. Musyafir Ulfah, “Analisis Tindak Tutur Perlokusi Pada Kumpulan Cerpen 'Bibir' Karya Bakdi Soemanto," Kreatif 18, no. 1 (1995): 24-33.
} 
Hal sependapat disampaikan oleh Choudron ${ }^{14}$ bahwa tuturan guru dalam berinteraksi dengan siswa menjadi media untuk mentransfer ilmu yang sedang dikaji sehingga menjadikan siswa lebih aktif untuk bertanya, memberikan respon atas apa yang dituturkan oleh guru sehingga dapat diketahui sejauhmana keberhasilan pembelajaran yang telah dilaksanakan.

Untuk mewujudkan pola interaktif yang multiarah antara siswa dan guru dalam mempelajari materi Bahasa Arab maka diperlukan kemampuan yang baik dalam bekerjasama antara penutur (guru) dan mitra tutur (siswa). Yayuk sependapat dengan teori tersebut. ${ }^{15}$

Grice dalam Ristiawan ${ }^{16}$ dan Adebola ${ }^{17}$ dan Qassemi ${ }^{18}$ menggagas teori prinsip kerjasama yang bermanfaat untuk menjadikan kelancaran dalam berkomunikasi pembelajaran Bahasa Arab. I Made Arta ${ }^{19}$. Riris ${ }^{20}$ dan

14 Choudron, C, Second Language Classroom: Research on Teaching and Learning (Cambridge: Cambridge University Press, 1988), hlm. 34.

15 Yayuk Sebtiana, "Tuturan Lokusi, Ilokusi, Dan Perlokusi Dalam Interaksi Pembelajaran Siswa Kelas VII Di SMP Negeri 2 Jumapolo," Universitas Muhammadiyah Surakarta (Universitas Muhammadiyah SUrakarta, 2018).

16 H. Ristiawan, "Prinsip Kerja Sama Dalam Berinteraksi Di Lingkungan SMPN 11 Kota Jambi," Pena 7, no. 2 (2017): 99-116, https://onlinejournal.unja.ac.id/pena/article/view/4768. hlm. 100

17 Otemuyiwa Abosede Adebola, "Cooperative Principle Maxims In Whatsapp Conversations Among Undergraduates In The Federal University Of Technology Akure, Ondo State, Nigeria," Advances in Social Sciences Research Journal 5, no. 10 (2018): 542-57, https://doi.org/10.14738/assrj.510.5309.

18 Mohsen Qassemi, Roya Sedigh Ziabari, and Iran Reza Kheirabadi, "Grice\&quot;s Cooperative Principles in News Reports of Tehran Times-A Descriptive-Analytical Study," International Journal of English Language \& Translation Studies, 2013, 66-74, www.eltsjournal.org.

19 I Made Rai Arta, "Prinsip Kerjasama Dan Kesantunan Pada Pembelajaran Bahasa Indonesia Dengan Pendekatan Saintifik," Palapa: Jurnal Studi Keislaman Dan Ilmu Pendidikan 4, no. 2 (2016): 139-51.

20 Riris Tiani, “Penyimpangan Maksim Kualitas Dan Kuantitas Dalam Humor Sutra ' Di Tabloid Mantra," in Seminar Nasional Prasasti (Pragmatik: Sastra Dan Linguistik), 2017, 17379. 
Nuruddin $^{21}$ menambahkan fungsi dari pelaksanaan prinsip ini yakni mewujudkan kelancaran suasana pembelajaran, siswa terlibat aktif dalam aktivitas pembejaran dan mempermudah ketercapaian tujuan pembelajaran. I nyoman ${ }^{22}$ dan $\operatorname{Pan}^{23}$ menambahkan dengan pematuhan ini akan mengefesiensikan waktu yang diperlukan dalam interkasi kelas pembelajaran bahasa Arab. Salah satu maksim yang harus dipatuhi kaedahnya adalah maksim Kuantitas (المبدأ الكمي). Maksim ini menuntut guru dan siswa dalam interaksi kelas menggunakan tuturan yang singkat, jelas dan tidak berlebihan. Wafiqotin ${ }^{24}$ menambahkan bahwa dengan mematuhi maksim ini akan memberikan kemudahan bagi siswa untuk memahami bahan yang dipelajari secara benar dan sesuai fakta tanpa pengurahan ataupun penambahan.

Penelitian ini hanya berfokus pada salah satu maksim yakni maksim kuantitas. Maksim ini sangat mendominasi dalam kegiatan interaksi Bahasa Arab. Banyak Penelitian tentang penggunaan maksim kuantitas sebagai salah satu Prinsip Kerjasama Grice, diantaranya penelitian yang dilakukan oleh Shofiyah Ilmi Syafri (2018), Ni Wayan Eminda Sari (2013), dan I Made Rai Arta (2016).

21 Nuruddin Asyifa Ulam, Emzir, "Analisis Linguistik Prinsip Kerjasama Dalam Tuturan Cerita Humor Nawadir Juha Li Al-Athfal," Arabi: Journal of Arabic Studies 3, no. 2 (2018): 15766, https://doi.org/http://dx.doi.org/10.24865/ajas.v3i2.84 ANALISIS.

22 I Nyoman Payuyasa et al., "Guru Dan Siswa Dalam Pembelajaran Bahasa Dan Sastra Indonesia Di Kelas Xi Sma Negeri 1 Blahbatuh Students Speech Acts in Learning Indonesian Language and Literature In" 3, no. 3 (2014).

23 Weiwei Pan, "Linguistic Basis of Humor in Uses of Grice's Cooperative Principle," International Journal of Applied Linguistics and English Literature 1, no. 6 (2012): 20-25, https://doi.org/10.7575/ijalel.v.1n.6.p.21.

24 Wafiqotin Nazihah and Gigit Mujianto, "Maksim Kuantitas Pada Ragam Kolokial Dalam Sentra Pelayanan Publik," Alinea: Jurnal Bahasa, Sastra, Dan Pengajaran 9, no. 2 (2020): 85, https://doi.org/10.35194/alinea.v9i2.951. 
Shofiyah ${ }^{25}$ (2018) menyusun artikel berjudul "Penggunaan Maksim Kuantitas (المبدأ الكمي) dan Kualitas (المبدأ الكيفي) dalam Proses Pembelajaran Bahasa Indonesia Siswa Kelas IX SMPN 3 Wonomulyo. Penelitian ini mengkaji pematuhan dan pelanggaran maksim kuantitas (المبدأ الكمي) dan kualitas المبدأ (المئ) ( الكيفي) dalam proses pembelajaran bahasa Indonesia siswa Kelas IX di SMPN 3 Wonomulyo. Hasil penelitian menunjukkan bahwa ditemukan enam bentuk pematuhan maksim Grice yang berjenis maksim kuantitas dan kualitas; (2) Pelanggaran maksim Grice yang tergolong pada kelompok Maksim kuantitas dan kualitas ditemukan dalam empat bentuk.

Ni Wayan (2013)26 menyusun artikel berjudul "Pelaksanaan Prinsip Kerjasama dalam Percakapan Guru dan Siswa Serta Dampaknya Terhadap Pembelajaran Bahasa Indonesia di Kelas XI SMAN I Kediri. Penelitian ini mengkaji tentang Prinsip Kerjasama yang dilaksanakan oleh guru dalam kegiatan bercakap dengan siswa. Selain itu juga memngkaji tentang dampak pelaksanaan prinsip ini terhadap proses belajar Bahasa Indonesia. Hasil dari penelitian menunjukkan, 1) konteks pembelajaran (السياق التعليمية)baik formal maupun non formal merupakan tempat dimana guru melaksanakan prinsip kerjasama. Dan konteks situasi formal lebih mendominasi di kelas yakni pada saat guru menjelaskan pelajaran; 2) Pelaksanaan prinsip kerjasama guru terlihat pada pematuhan maksim kuantitas (المبدأ الكمي), kualitas (المبدأ الكيفي), relevansi (المبدأ العلاقة) dan maksim cara ( المبدأ الحال)dalam kegiatan proses pembelajaran; 3) Pelaksanaan empat prinsip yang dilakukan oleh siswa juga

25 S I Syafri, "Penggunaan Maksim Kuantitas Dan Kualitas Dalam Proses Pembelajaran Bahasa Indonesia Siswa Kelas Ix Smpn 3 Wonomulyo," Core.Ac.Uk, 2018, https://core.ac.uk/download/pdf/185622835.pdf.

${ }^{26}$ Ni Wayan Eminda Sari, "Pelaksanaan Prinsip Kerja Sama Dalam Percakapan Guru Dan Siswa Serta Dampaknya Terhadap Pembelajaran Bahasa Indonesia Di Kelas Xi Sman I Kediri," Jurnal Santiaji Pendidikan (JSP) 3, no. 2 (2013): 178-88, https://doi.org/10.36733/jsp.v3i2.493. 
diketahui pada pematuhan empat maksim tersebut dalam kegiatan proses pembelajaran; 4) pelaksanaan prinsip ini berdampak pada kenyamanan dan kekondusifan situasi pembelajaran, perkembangan keaktifan siswa di kelas, tercapainya tujuan pembelajaran.

I Made Arta ${ }^{27}$ menyusun artikel berjudul "Prinsip Kerjasama dan Kesantunan pada Pembelajaran Bahasa Indonesia dengan Pendekatan Saintifik". Penelitian ini mengkaji prinsip kerjasama (المبدأ التعاوني) dan kesantunan (المبدأ التأدبي) yang berorientasi pada pembelajaran bahasa di kelas. Dari penelitian ini diketahui bahwa keaktifan siswa dalam berinteraksi di kelas memunculkan prinsip kerjasam dan prinsip kesantunan. Dan guru dituintut memiliki komitmen tinggi untuk selalu bekerjasama untuk mewujudkan keefektifan pebelajaran dan tercapainya tujuan yang diharapkan.

Dalam penelitian ini, peneliti akan mengkaji tentang pematuhan maksim kuantitas (المبدأ الكمي) pada tuturan guru dalam interaksi kelas bahasa Arab. Hal ini berbeda dengan beberapa penelitian yang telah disebutkan sebelumnya. Penelitian ini perlu dilakukan untuk menganalisa tuturan tepat yang mematuhi maksim kuantitas yang berfungsi sebagai masukan bermakna bagi siswa dalam pembelajaran bahasa Asing, Dengan masukan bermakna tersebut, siswa akan mampu meningkatkan kemahiran berbahasa mereka baik kemahiran mendengar, membaca, berbicara dan menulis dalam bahasa Asing.

\section{METODE PENELITIAN}

Artikel ini bertujuan mengkaji pematuhan maksim kuantitas tuturan guru yang digunakan dalam kegiatan interaksi antara guru dan murid di kelas

27 I Made Rai Arta, "Prinsip Kerjasama Dan Kesantunan Pada Pembelajaran Bahasa Indonesia Dengan Pendekatan Saintifik." 
Bahasa Arab. Pendekatan penelitian ini yakni kualitatif dengan berjenis studi kasus.

Penelitian ini dilaksanakan di Kelas XII Madrasah Aliyah Al-Munawaroh Ngemplak Ngudirejo yang menjadi fokus sumber datanya yakni guru Bahasa Arab Bapak Amin Awwaluddin, M. PdI di Kelas XII. Sesuai dengan tujuan penelitian berupa tuturan yang diucapkan oleh guru bahasa Arab menjadi data penelitian ini yang menginformasikan adanya tuturan yang mematuhi indikator dari maksim kuantitas yang diperoleh melalui observasi dengan cara perekaman. Analisa data dilakukan secara interaktif yakni pengumpulan data, reduksi data, penyajian data dan penarikan kesimpulan.

\section{PEMBAHASAN}

Pematuhan maksim kuantitas pada tuturan guru digunakan pada beberapa kategori yakni, 1) Requestives "Memohon", 2) Requestives "Mendoa"; 3) Requestives Meminta ; 4) Questions "bertanya"; 5) Questions "menyelidik", dan 3) Prohibitives "Melarang".

\section{1) Kategori Requestives "Memohon"}

Memohon merupakan melakukan permintaan yang dilakukan secara sopan oleh penutur (guru) dan mitra tutur (siswa) atas apa yang sedang diinginkan. Data temuan penelitian menunjukkan bahwa tuturan Kategori Requestives "Memohon digunakan ketika guru memberikan kesempatan siswa untuk mengembangkan ketrampilan komunikasi dan berbahasa mereka. Hal tersebut ditunjukkan pada data (1) berikut.

(1) Guru

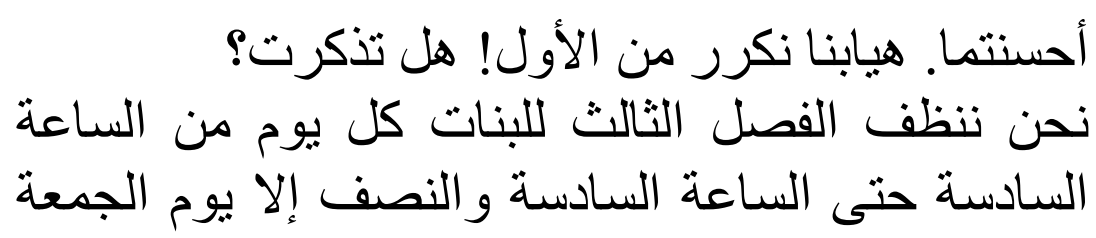

Siswa 


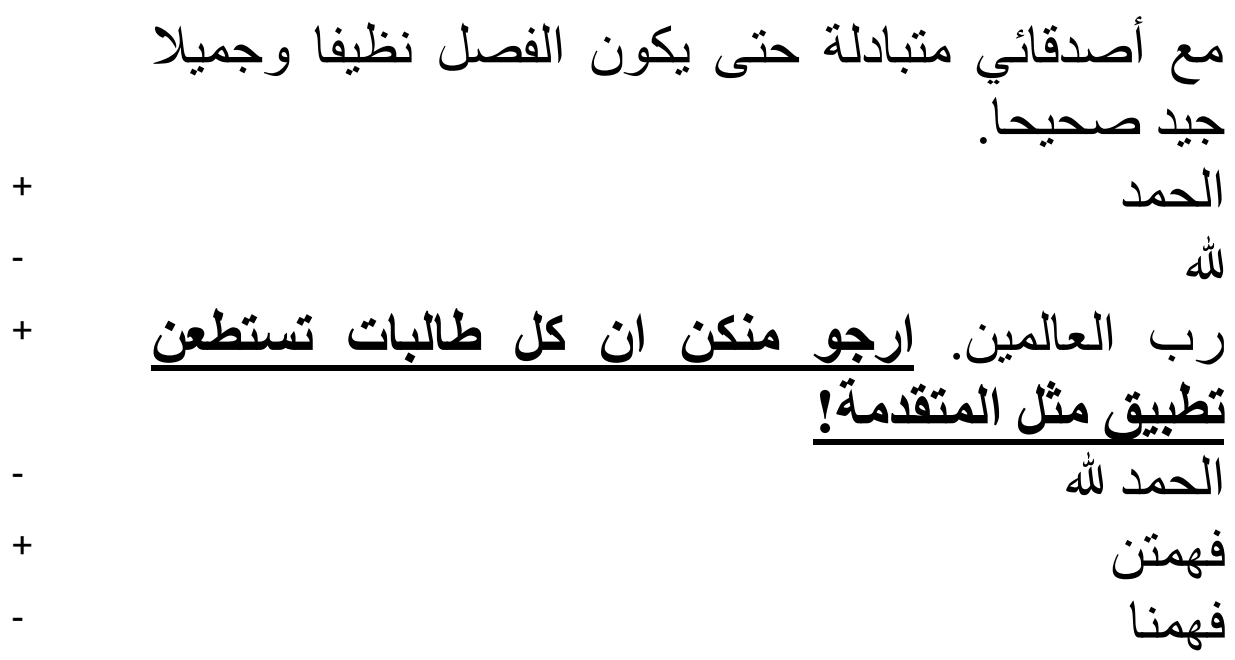

Respons Siswa (رد الطلاب): Respons verbal (الرد اللفظي) dan non verbal الرد ) :غير اللفظي): Siswa memperhatikan permohonan guru dan menjawab dengan kata "Alhamdulillah"

Konteks : Dituturkan guru setelah siswa bercakap-cakap di depan kelas dengan permainan "Tanmiyah al-Jumlah"

Pada data (1) di atas, guru menggunakan maksim kuantitas pada أرجو 66 tuturannya Pada tuturan ini guru menggunakan mood imperative "منكن artinya saya berharap. Kata tersebut secara leksikal bermakna "saya berharap". Kata kerja bermakna harapan tersebut secara literal berfungsi untuk memohon sesuatu pada seseorang. Tuturan ini digunakan setelah guru memerintah dua siswa untuk maju ke depan kelas untuk bercakap-cakap bahasa Arab dengan permainan "tanmiyah al-Jumlah". Kemudian guru memohon siswa yang lain untuk mengulangi percakapan temannya. Dan permohonan ini berdasarkan evaluasi atas percakapan terbaik temannya. Oleh karena itu, dengan tuturan ini digunakan untuk mengembangkan kemahiran siswa dalam berinteraksi dengan berbahasa Arab. respons siswa atas tuturan tersebut berupa respons verbal dan non verbal yakni memperhatikan anjuran guru dan menjawab dengan kata "Alhamdulillah".

Data tersebut menunjukkan adanya kelancaran dalam berinteraksi, hal ini diketahui dari respons yang diberikan oleh siswa sebagai mitra tutur. Dia memahami apa yang diucapkan oleh guru yang mana dengan mematuhi maksim kuantitas. Bukti akan hal itu adalah siswa langsung 
menjawab dengan jawab yang tegas dan tepat yaitu dengan kata alhamdulilah. Pencapaian tujuan interaksi tersebut karena adanya kepatuhan pada salah satu prinsip kerjasama mabda' al-Ta'awuniy siswa mengacu pada prinsip yang melatarbelakanginya. Dengan penggunaan prinsip ini, siswa berusaha memberikan respons sesuai yang diinginkan guru.

Data penggunaan maksim kuantitas pada tuturan guru dengan modus memohon juga dipergunakan pada kegiatan apersepsi pembelajaran. Adapun kutipan data tersebut adalah:

(2) Guru:
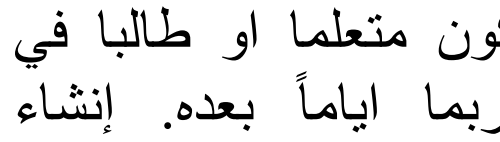

Siswa
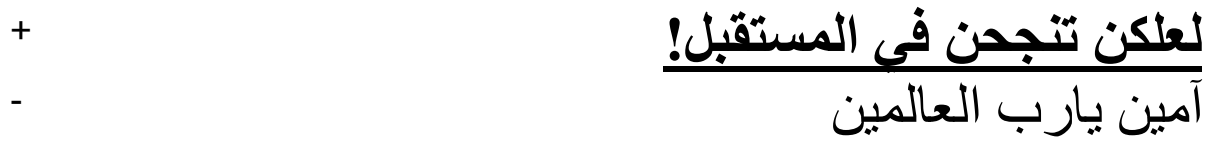

Respon: Respon verbal: Menjawab harapan guru dengan kalimat آمين

Konteks : Dituturkan guru pada saat memulai pembelajaran dan memotivasi siswa

Tuturan pada kutipan data (2) di atas menunjukkan fungsi direktif memohon. Melalui tuturan itu guru memohon dengan halus pada siswa agar memiliki cita-cita untuk melanjutkan sekolah sampai jenjang S3, kemudian guru memohon agar siswa selalu memiki semangat yang tinggi ketika belajar dan tidak berhenti sekolah di aliyah saja. Data ini mendapat respon dari siswa berupa respon verbal pada data 1 yaitu dengan kata ami...n. respon siswa tersebut menunjukkan bahwa siswa juga mendukung apa yang telah diminta oleh guru. 
Permohonan halus pada kutipan data di atas ditandai dengan kata permohonan yaitu kata لعل Kata tersebut merupakan leksikon dalam bahasa arab yang khusus digunakan untuk memohon dengan sopan. Dengan pilihan diksi yang tepat untuk memerintahkan siswa diharapkan siswa merasa dihargai dan merasa semangat untuk terus belajar dan melanjutkan sekolah lagi.

Kelancaran interaksi kelas antar guru dan murid ini karena penggunaan maksim kuantitas pada proses pembelajaran. Pematuhan ini ditandai dengan respons siwa secara tegas yaitu dengan kata Aamiin pada harapan yang disampaikan oleh guru tidak berlebihan. Dengan penggunaan prinsip ini, siswa berusaha memberikan respons sesuai yang diinginkan guru.

\section{2) Kategori Requestives "Mendoa"}

Mendoa secara bahasa memiliki makna memohon (mengaharap, meminta dan memuji) kepada Allah. Permohonan ini bersifat satu arah yakni aktivitas meminta dari sorang manusia kepada tuhannya. Tuturan berkategori "mendoa" dalam bahasa Arab memiliki kekhasan dalam pemarkahnya. Beberapa tuturan yang diucapkan oleh Ustadz Amin dalam kegiatan interaksi pada pembelajaran Bahasa Arab di MA Al-Munawaroh sebagai berikut.

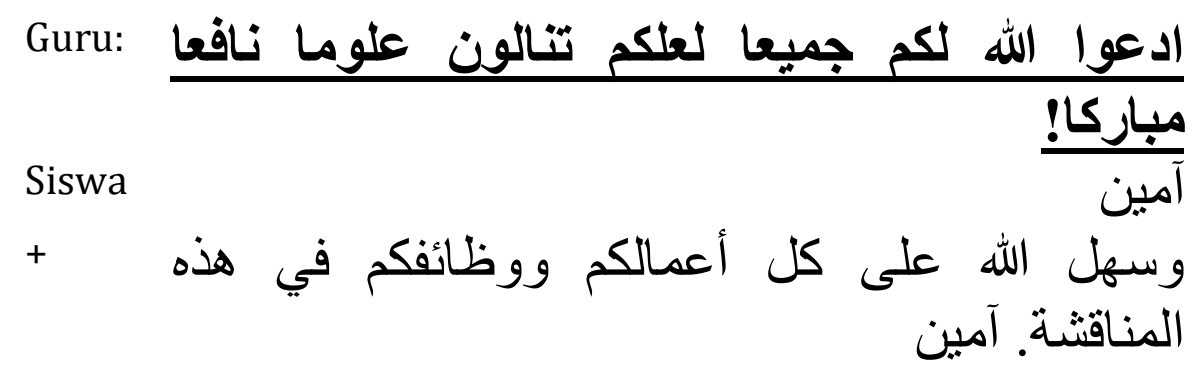




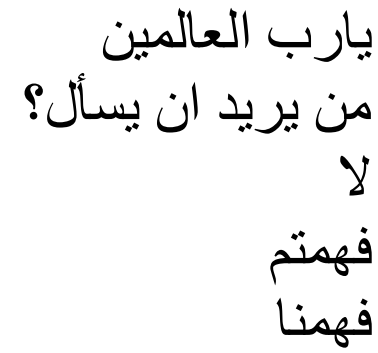

Respons Siswa (رد الطلاب): Respons verbal (الرد اللفظي) dan non verbal (الرد غير اللفظي): Siswa memperhatikan doa guru dan menjawab dengan kata "Aamiin"

Konteks : Dituturkan guru pada kegiatan akhir proses pembelajaran

Pematuhan maksim kuantitas digunakan oleh guru pada kegiatan akhir pembelajaran demi tercapainya kompetensi spiritual terlihat pada data (3).Data tersebut merupakan tuturan digunakan oleh guru untuk mendoa kepada Allah . Tuturan mendoa tersebut dengan menggunakan kalimat kata kerja yang khusus yang memiliki makna sebuah harapan atau doa kepada Allah yaitu kata ادعوا الله. Kata tersebut secara leksikal bermakna "saya berdoa" Kata kerja bermakna do'a tersebut secara literal berfungsi untuk meminta harapan yang kita inginkan pada Allah. Tuturan ini digunakan guru setelah mempelajari materi "الحضارة الإسلامبة" dan mengerjakan soal-soal dalam LKS. Setelah proses pembelajaran tersebut, guru dan berdoa kepada Allah agar menjadikan ilmu yang dipelajari bermanfaat dan mempermudah segala tugas. Penggunaan kata ini tidak memerlukan pada konteks yang melatar belakanginya sehingga memudahkan siswa untuk merespons tuturan guru. Respon siswa berbentuk respon verbal dan non verbal yakni perhatian siswa pada tuturan guru dan menjawabnya dengan kata "Aamiin".

Kelancaran interaksi pada kegiatan belajar mengajar Bahasa Arab terlihat pada data (3) karena tujuan yang diharapkan oleh penutur (guru 
tercapai. Alasan yang menjadi tercapainya tujuan pada interaksi kelas ini adalah terlaksananya maksim kuantitas. Pada data tersebut terlihat pada saat guru menyuruh siswa untuk berdoa kepada allah agar dikaruniai ilmu yang manfaat. Maksim kuantitas (المبلأ الكمي) ini memberikan kewajiban bagi siswa untuk menjawab dengan kalimat yang singkat, yakni siswa merespons dengan kata "Aamiin". Penggunaan tuturan tersebut bertujuan untuk tercapainya tujuan pembelajaran yang diharapkan dan mempermudah siswa untuk memahami apa yang diinginkan oleh guru.

Data penggunaan maksim kuantitas pada tuturan guru dengan modus mendoa juga dipergunakan pada kegiatan akhir pembelajaran. Adapun kutipan data tersebut adalah:

(4) Guru:

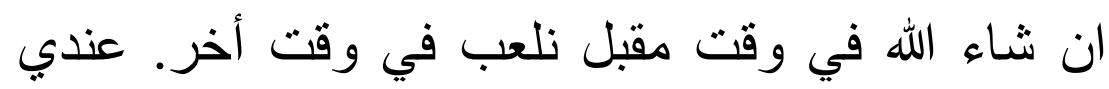
العاب كثيرة.

Siswa

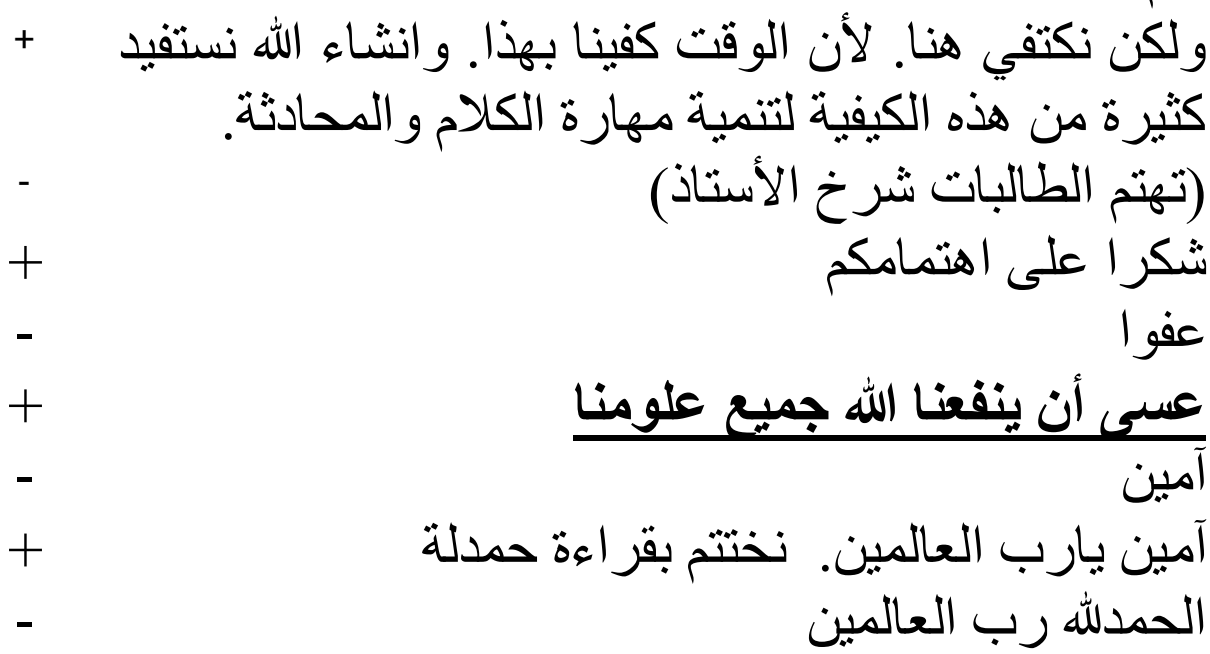

Respons Siswa (رد الطلاب): Respons verbal (الرد اللفظي) dan non verbal الردب) : غير اللفظي): Siswa memperhatikan doa guru dan menjawab dengan kata "Aamiin"

Konteks : Dituturkan guru pada kegiatan akhir proses pembelajaran 
Maksim kuantitas digunakan oleh guru pada kegiatan akhir pembelajaran demi tercapainya kompetensi spiritual terlihat pada data (4). Data tersebut merupakan tuturan digunakan oleh guru untuk berharap kepada Allah. Tuturan mendoa tersebut dengan menggunakan kalimat kata kerja yang khusus yang memiliki makna sebuah harapan atau doa kepada Allah yaitu kata عسى الله. Kata tersebut secara leksikal bermakna "saya berharap kepada Allah" Kata kerja bermakna do'a tersebut secara literal berfungsi untuk meminta harapan yang kita inginkan pada Allah. Tuturan ini digunakan guru setelah mempelajari materi alat transportasi menghafalkannya dengan permainan bahasa. Setelah proses pembelajaran tersebut, guru dan berdoa kepada Allah agar menjadikan ilmu yang dipelajari bermanfaat dan mempermudah segala tugas. Penggunaan kata ini tidak memerlukan pada konteks yang melatar belakanginya sehingga memudahkan siswa untuk merespons tuturan guru. Respon siswa berbentuk respon verbal dan non verbal yakni perhatian siswa pada tuturan guru dan menjawabnya dengan kata "Aamiin".

Proses interaksi antara guru dan murid pada data tersebut berjalan lancar, tujuan penutur tercapai sesuai dengan yang diharapkan kepada Allah. Alasan yang menjadi tercapainya tujuan pada interaksi kelas ini adalah terlaksananya maksim kuantitas. Pada data tersebut terlihat pada saat guru menyuruh siswa untuk berdoa kepada allah agar dikaruniai ilmu yang manfaat. Maksim kuantitas ini mewajibkan setiap peserta percakapan mengatakan hal yang singkat. Lalu siswa merespons dengan kata "Aamiin". Penggunaan tuturan tersebut bertujuan untuk tercapainya tujuan pembelajaran yang diharapkan dan mempermudah siswa untuk memahami apa yang diinginkan oleh guru.

Data penggunaan maksim kuantitas pada tuturan guru dengan modus mendoa juga dipergunakan pada kegiatan inti pembelajaran. Adapun kutipan data tersebut adalah:

(5) Guru

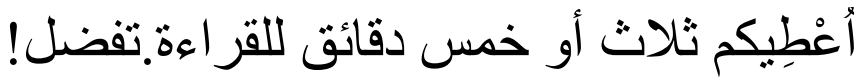

Siswa
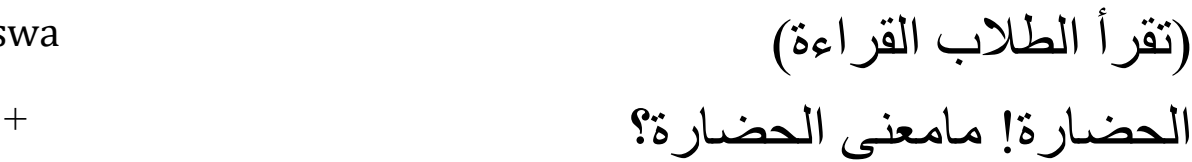

$-$

Peradaban

$+$

أو Pebudayaan Peradaban 


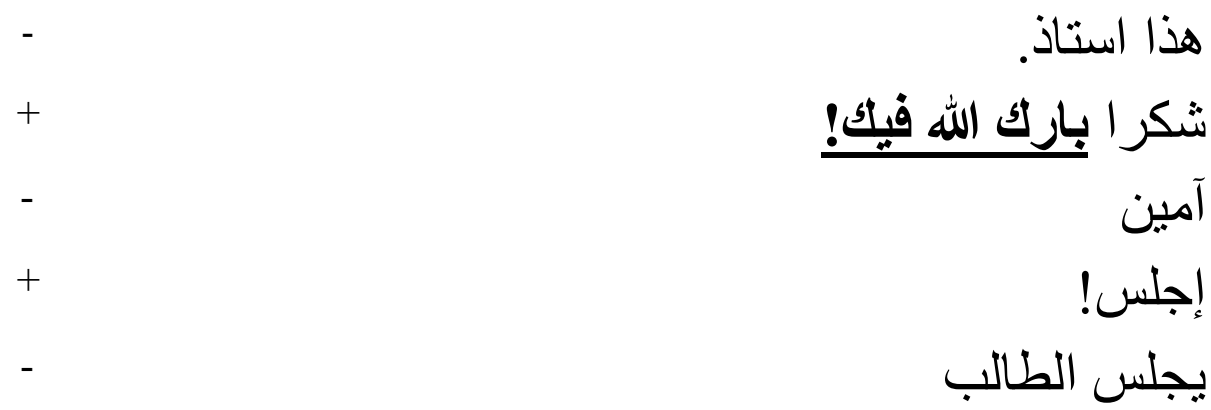

Respons Siswa (رد الطلاب): Respons verbal (الرد اللفظي) dan non verbal الرد غير) (اللفظي: Memperhatikan guru dan menjawab doa guru

Konteks: Dituturkan pada saat memulai pelajaran. Dan guru meminta dia untuk mengambilkan buku di kantor.

Maksim kuantitas digunakan oleh guru pada kegiatan apersepsi demi tercapainya kompetensi spiritual terlihat pada data (5). Data tersebut merupakan tuturan digunakan oleh guru untuk mendoakan keberkahan bagi siswa kepada Allah. Tuturan mendoa tersebut dengan menggunakan kalimat kata kerja yang khusus yang memiliki makna sebuah harapan atau doa kepada Allah yaitu kata بارك الله Kata tersebut secara leksikal bermakna "semoga Allah memberkati" Kata kerja bermakna do'a tersebut secara literal berfungsi untuk meminta harapan yang kita inginkan pada Allah. Tuturan ini digunakan guru ketika mempelajari materi "الحضارة الإسلامية". Pada saat proses pembelajaran tersebut, guru meminta siswa mengambilkan buku di kantor, Lalu beberapa seat ketika guru membahas materi, siswa meberikaan buku itu, Kemudian guru mendoakananya kepada Allah agar memberkahi hidupnya sebagai ucapan terima kasihnya. Penggunaan kata ini tidak memerlukan presuposisi sehingga memudahkan siswa untuk merespons tuturan guru. Respon siswa berbentuk respon verbal dan non verbal yakni perhatian siswa pada tuturan guru dan menjawabnya dengan kata "Aamiin".

Kegiatan interaksi antara guru dan murid telah berjalan dengan baik sehingga meudahkan tercapainya tujuan yang diharapkan. Bukti bahwa tujuan telah tercapai pada aktivitas ini adalah dengan penggunaan maksim kuantitas. Pada data tersebut terlihat pada saat siswa melaksanakan perintah guru, Guru mendoakannya kepada Allah agar diberkahi hidupnya. Pematuhan maksim kuantitas ini mewajibkan setiap peserta percakapan mengatakan hal yang singkat. Lalu siswa merespons 
dengan kata "Aamiin". Penggunaan tuturan tersebut bertujuan untuk tercapainya tujuan pembelajaran yang diharapkan dan mempermudah siswa untuk memahami apa yang diinginkan oleh guru.

Data (3), (4) dan (5) di atas menunjukkan tuturan guru yang أدعو الله، عسسى الله، memiliki kategori "mendoa”. Tuturan tersebut yakni Ketiga kalimat tersebut selalu bergandengan dengan Kalimat “ الله “ yang memiliki makna secara khusus yakni mengharap kepada Allah untuk diberikan apa yang diinginkan.

Beberapa kutipan data di atas menunjukkan sebuah harapan pada tuhan untuk memberi keberkahan kepada siswanya. Harapan tersebut dikategorikan tuturan "mendoa" karena harapan hanya ditujukan kepada Allah.

\section{3) Kategori Requestives Meminta}

Meminta bermakna berkata-kata supaya diberi atau mendapat sesuatu. Data Penggunaan maksim kuantitas pada tuturan guru dengan kategori ini dalam proses belajar bahasa Arab di MA Al-Munawaroh ditunjukkan pada data (3) berikut.

(6) Guru:
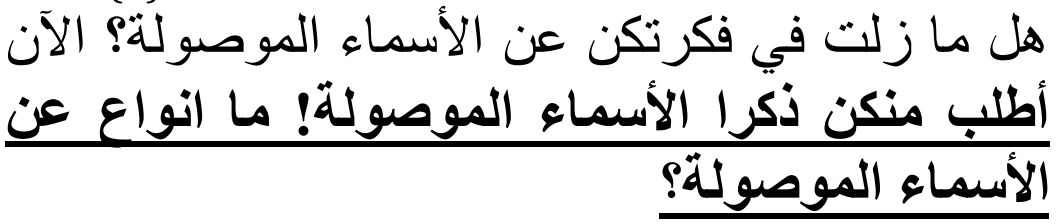

Siswa

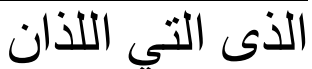

$+$

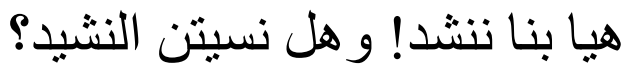

$-$

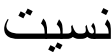

$+$

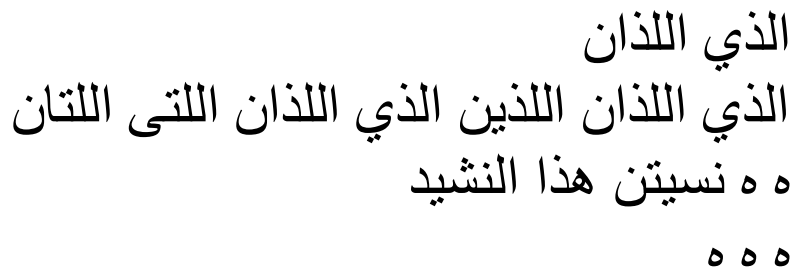

Respons Siswa: Respons verbal: Siswa mengingat materi isim maushul Konteks : Dituturkan guru pada saat guru menerangkan materi الحضنارة"

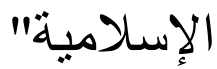


Maksim kuantitas juga dipatuhi pada interaksi kelas pada kegiatan inti pembelajaran. Data tersebut merupakan tuturan digunakan oleh guru untuk mengetahui sejauhmana tingkat pemahaman atas materi yang telah dipelajari oleh siswa sebelumnya. Tuturan tersebut menggunakan kalimat mood imperatif yang memiliki makna sebuah permintaan dengan menggunakan kata itu sendiri yaitu kata أطظب. Secara leksikal, kata tersebut bermakna "saya meminta" Kata kerja bermakna permintaan tersebut secara literal berfungsi untuk meminta seseorang untuk melakukan apa yang dia inginkan. Tuturan ini diucapkan oleh guru pada saat mempelajari materi dan mengerjakan soal-soal dalam LKS. Pada saat membahas soal tentang isim maushul, guru ingin mengetahui kemampuan mahasiswa dalam qoidah yang telah dipelajari. Guru meminta mereka untuk menyebutkan isim-isim maushul dan macammacamnya dengan kata أطظب. Penggunaan kalimat ini tidak memerlukan Presuposisi sehingga memudahkan siswa untuk merespons tuturan guru karena menggunakan kata yang sesuai dengan maknanya. Respon siswa berbentuk respon verbal yakni siswa menyebutkan isim maushul.

Kegiatan interaksi terlihat lancar karena guru mematuhi maksim kuantitas yakni bertutur dengan kalimat yang singkat dan tidak berlebihan. Pada data tersebut terlihat pada saat guru menyuruh siswa menyebutkan isim maushul dan macam-macamnya dengan kalimat أطلب , maka siswa langsung menyebutkannya. Maksim kuantitas ini memberikan kewajiban bagi siswa untuk merespons dengan singkat sesuai yag diinginkan guru yakni menyebut isim maushul. Penggunaan tuturan tersebut bertujuan 
untuk tercapainya tujuan pembelajaran yang diharapkan dan mempermudah siswa untuk memahami apa yang diinginkan oleh guru.

\section{4) Kategori Questions Bertanya}

Salah satu dari kategori tindak tutur direktif tuturan guru di kelas adalah bertanya. Tuturan dengan kategori ini digunakan untuk meminta informasi terkait dengan tujuan komunikasi yang diharapkan guru dalam proses pembelajaran. Hasil penelitian menunjukkan bahwa fungsi meminta informasi diungkapkan dengan modus interogratif yakni kalimat diakhiri tanda tanya dan intonasi yang tinggi pada akhir kalimat. Adapun kutipan data tuturan yang menunjukkan kategori Questions bertanya dengan fungsi meminta informasi.

(7) Guru:

Siswa

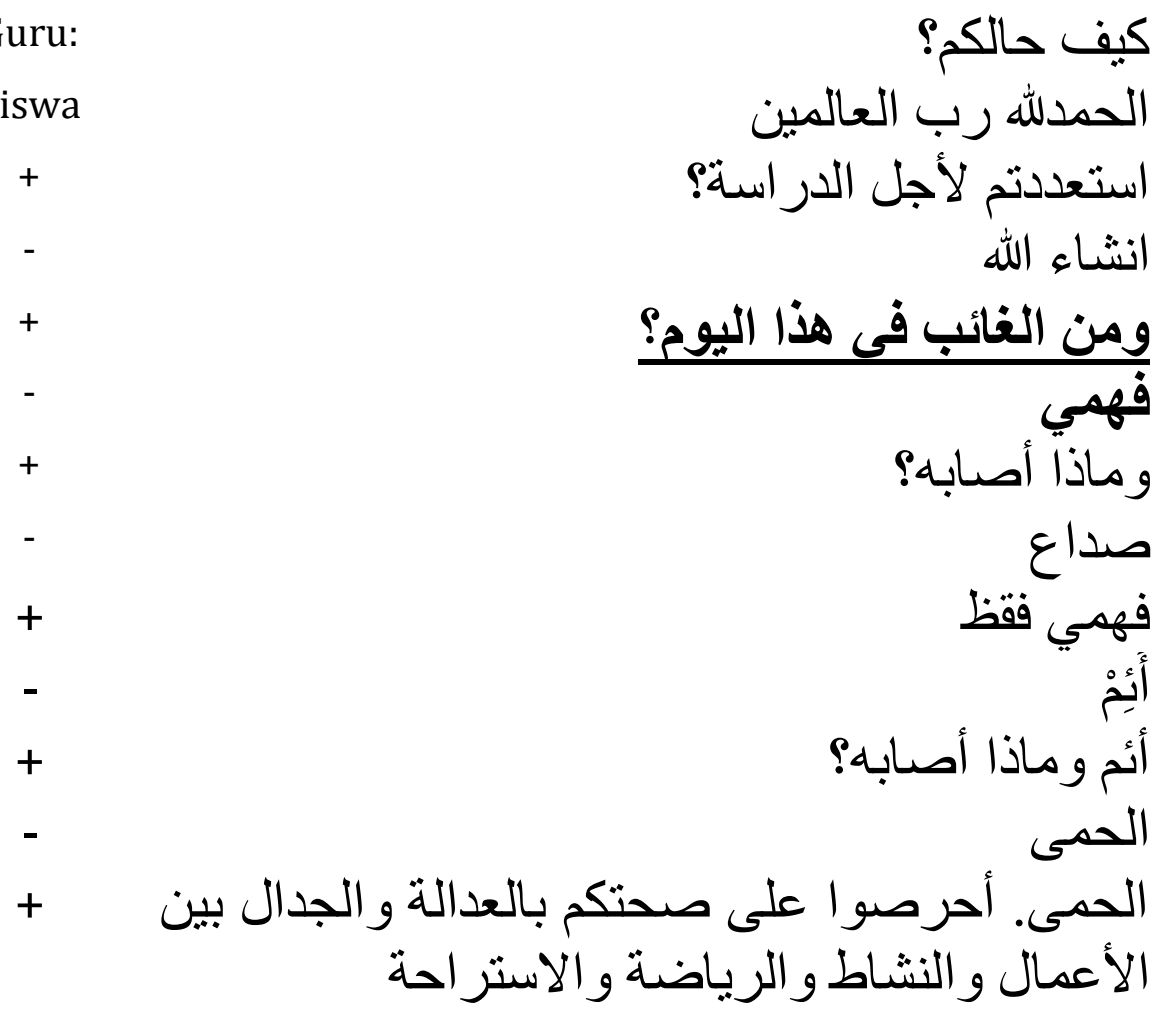

انشاء الله 
Respons Siswa (رد الطلاب): Respons verbal (الرد اللفظي) dan non verbal الرد) (غير اللفظي):Menjawab pertanyaan guru dan melihat siapa yang tidak hadir hari ini

Konteks: Dituturkan guru ketika meminta informasi siapa siswa yang tidak bisa datang pada hari ini

Kutipan data (7) menunjukkan penggunanan fungsi tuturan meminta informasi dalam modus interogatif. Tuturan diaplikasian pada saat awal pembelajaran ketika meminta informasi siswa yang tidak masuk sekolah. Melalui tuturan tersebut guru berharap menerima respon dari siswa terkait pertanyaan yang sudah dituturkan. Tuturan ditandai dengan intonasi tanya dan kata tanya man.

Berdasarkan kutipan jawaban data yang bergaris bawah siswa memberikan respon verbal, yaitu dengan menyebutkan nama siswa yang tidak masuk sekolah yang bernama fahmi. Tuturan ini diwujudkan untuk tujuan komunikasi yaitu guru bertanya untuk meminta informasi yang memang tidak diketahui dan berharap siswa mampu memberikan informasi dan juga memiliki fungsi agar siswa mau aktif berbicara.

Tercapainya tujuan komunikasi pada interaksi pembelajaran pada data tersebut terlihat lancar karena guru mematuhi prinsip pada maksim kuantitas. Pada data tersebut terlihat pada saat guru bertanya pada siswa memberikan informasi tentang siapa yang tidak masuk hari ini dengan kalimat ورن الغائب في هذا اليوم?, maka siswa langsung menjawabnya dengan kata "فهمي". Maksim kuantitas ini menuntut siswa untuk memberikan respons secara singkat tentang siap yang tidak hadir hari ini 
sesuai yag diinginkan guru. Penggunaan tuturan tersebut bertujuan untuk tercapainya tujuan pembelajaran yang diharapkan dan mempermudah siswa untuk memahami apa yang diinginkan oleh guru.

\section{5) Kategori Questions Menyelidik}

Tindak tutur mempunyai kategori brupa tindak tutur questions bermakna "menyelidik". Tuturan dengan kategori ini digunakan untuk meminta konfirmasi terkait dengan tujuan komunikasi yang diharapkan guru dalam interaksi pembelajaran di kelas. Tuturan dengan kategori Questions Menyelidik digunakan guru ketika proses apersepsi pembelajaran. Hal tersebut ditunjukkan pada data (8) berikut.

(8) Guru:

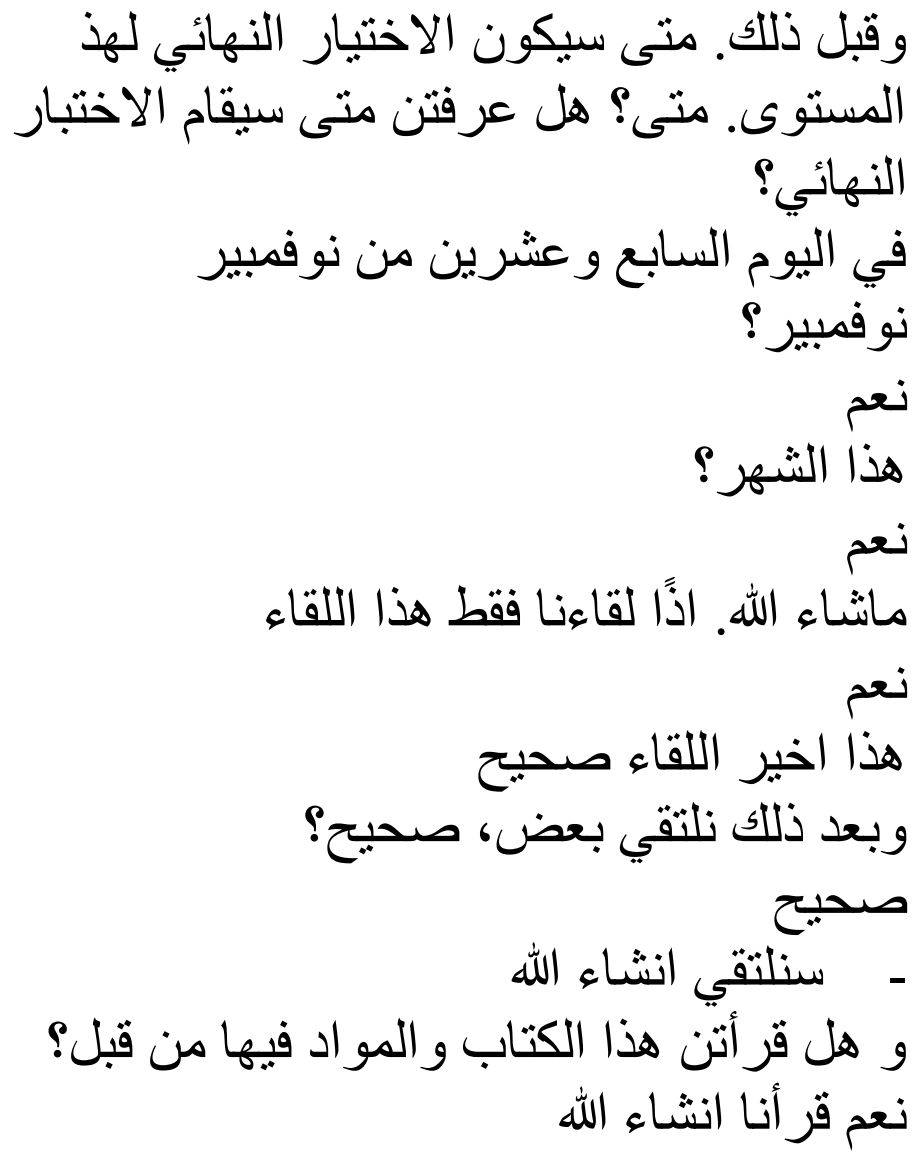




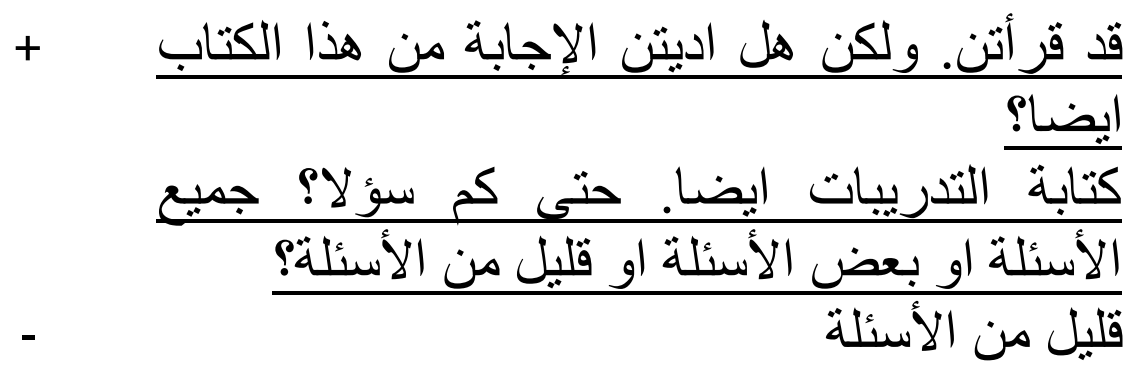

Respons Siswa: Respon verbal: Menjawab pertanyaan guru pada kesiapan siswa

Konteks: Dituturkan guru ketika kegiatan apersepsi pembelajaran

Tuturan guru dengan kategori Questions Menyelidik digunakan guru pada saat kegiatan apersepsi pembeajaran dengan meminta konfirmasi kesiapan siswa dalam modus interogatif. Harapan guru dengan menggunakan tuturan ini untuk menyelidik respon siswa terkait pertanyaan yang sudah dituturkan. Tuturan ditandai dengan intonasi tanya dan jenis pertanyaan alternatif (الأسئلة الذبلة) yang didahului oleh presuposisi mengandung makna pemberitahuan "قد قر أتن". Dan kata Tanya tersebut digunakan guru sebagai penegas kalimat pemberitahuan tersebut. Hal ini menunjukkan bahwa guru menyelidiki dengan santun sejauhmana kesiapan siswa dalam menghadapi ujian (امنحان).

Respons siswa atas tuturan guru berupa respons verbal yakni menjawab kesiapan ujian mereka. Tuturan ini diwujudkan untuk tujuan komunikasi yaitu guru bertanya untuk meminta konfirmasi yang memang tidak diketahui dan berharap siswa mampu memberikan konfirmasi dan juga memiliki fungsi agar siswa termotivasi untuk mau aktif berbicara.

Tercapainya tujuan komunikasi dalam kegiatan interaksi di kelas pada data tersebut ditandai dengan terpatuhinya maksim kuantitas. Pada 
data tersebut terlihat pada saat guru bertanya pada siswa memberikan informasi tentang siapa yang tidak masuk hari ini dengan kalimat كتابة التدريبات فرأتن. ولكن هل اديتن الإجابة من هذا الكتاب ايضا؟ ايضا. حتى كم سؤلا؟ جمبع الأسئلة او بعض الأسئلة او قليل من قايل من " maka siswa langsung menjawabnya dengan kata , الأسئلة؛ "الأسئلة:". Maksim kuantitas ini mewajibkan setiap peserta percakapan mengatakan hal yang singkat sesuai yag diinginkan guru. Penggunaan tuturan tersebut bertujuan untuk tercapainya tujuan pembelajaran yang diharapkan dan mempermudah siswa untuk memahami apa yang diinginkan oleh guru.

\section{6) Kategori Prohibitives "Melarang"}

Tindak tutur dengan kategori "Prohibitives" disampaikan oleh guru ketika proses permainan bahasa. Hal tersebut ditunjukkan pada data (9) berikut.

(9) Guru:

أنت أو لا من فضلك إ ابدئي بكلمة!

Siswa

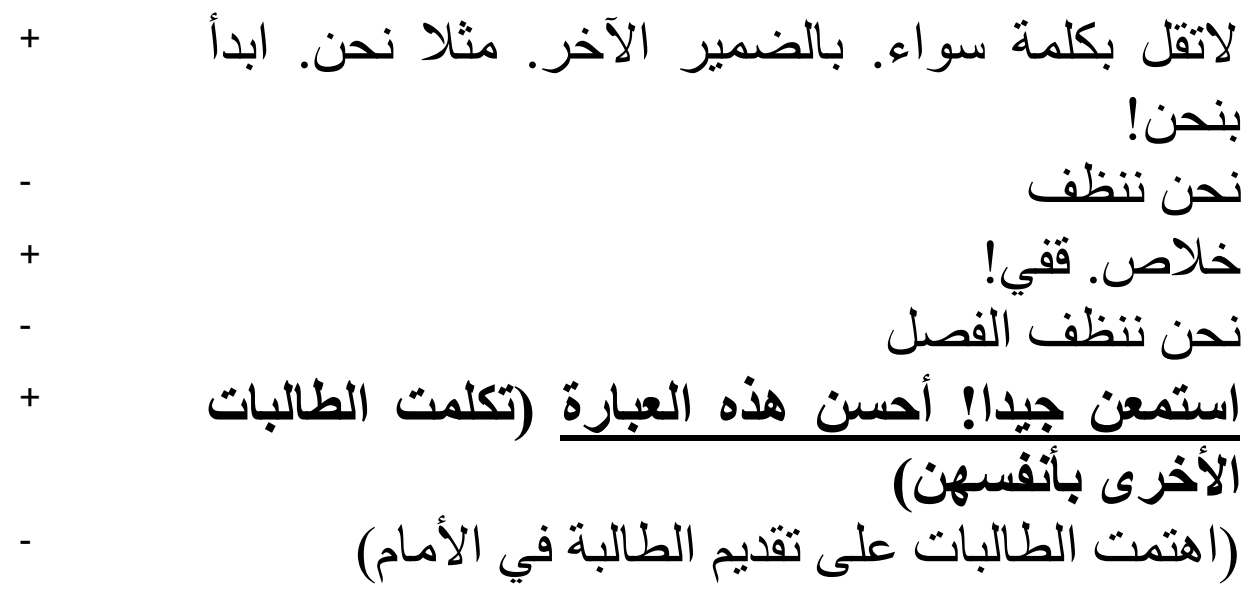




\section{نحن ننظف الفصل صباحا!}

Respons Siswa (رد الطلاب): Respons verbal (الرد اللفظي) dan non verbal الردي) : غير اللفظي):Siswa memperhatikan presentasi siswa di depan kelas dan dan mengulangi kalimat temannya

Konteks : Dituturkan guru ketika dua siswa diminta bercakap-cakap di depan kelas menggunakan permainan bahasa "tanmiyah al-Jumlah"

Pematuhan maksim kuantitas juga digunakan oleh guru pada kegiatan inti pembelajaran. Pematuhan tersebut berfungsi memusatkan perhatian siswa pada materi yang dipelajari. Hal ini ditunjukkan pada data (9).

Data tersebut merupakan tuturan diucapkan oleh guru untuk memberikan larangan bagi siswa untuk melaksanaka sesuatu dengan menggunakan kata perintah "استمعن")". Kata tersebut secara leksikal bermakna "dengarkanlah" Kata perintah tersebut dalam konteks ini bermakna perintah. Secara literal, kata ini berfungsi untuk memerintah siswa untuk melakukan sesuatu. Tuturan ini digunakan guru pada saat proses pembelajaran berlangsung yakni kegiatan pembuatan jumlah mufidah dengan permainan bahasa "Tanmiyah al-Jumlah". Kemudian guru menyuruh dua orang siswa untuk berdiri di depan bermain pengembangan kalimat dari satu kalimat ke kalimat lainnya. Pada saat siswa yang di depan bercakap-cakap, ada beberapa siswa yang tidak memperhatikan dan berbicara sendiri. Kemudian guru menyuruhnya untuk mendengarkan temannya yang sedang bermain di depan dan memperhatikan kalimat bahasa Arab yang sedang diucapkan oleh temannya. Penggunaan kata ini meskipun memerlukan pada konteks yang melatar belakangi penggunaannya, akan tetapi hal ini memudahkan siswa untuk merespons tuturan guru. Tuturan ini digunakan guru untuk menyindir siswa untuk 
diam dan memusatkan perhatian siswa pada kegiatan pembelajaran yang sedang berlangsung sehingga dengan tuturan yang tidak berlebihan ini mampu menjadikan interaksi antara guru dan siswa lebih efisien. Respon siswa berbentuk respon verbal dan non verbal yakni perhatian siswa pada larangan guru dan mengulangi kalimat temannya.

Kelancaran proses komunikasi dalam interaksi pembelajaran terlihat pada data tersebut karena tercapainya tujuan guru dalam bertutur yakni melarang siswa berbicara dan memintanya untuk memperhatikan temannya. Alasan yang menjadi tercapainya tujuan pada interaksi kelas ini adalah terpatuhinya maksim kuantitas. Pada data tersebut terlihat pada saat guru melarang siswa dengan kalimat perintah sehingga kalimat larangan tersebut tidak terkesan berlebihan dan lebih mudah dipahami oleh siswa. Maksim kuantitas ini mewajibkan setiap peserta interaksi bertutur tidak berlebihan. Penggunaan tuturan tersebut bertujuan untuk tercapainya tujuan pembelajaran yang diharapkan dan mempermudah siswa untuk memahami apa yang diinginkan oleh guru.

\section{Simpulan}

Berdasarkan hasil penelitian diketahui bawa pematuhan maksim kuantitas pada tuturan guru digunakan pada beberapa kategori yakni, 1) Requestives "Memohon", 2) Requestives "Mendoa"; 3) Requestives "Meminta; 4) Questions "bertanya"; 5) Questions "menyelidik", dan 6) Prohibitives "Melarang".

\section{Saran}

Hasil penelitian tentang pematuhan maksim kuantitas pada interaksi guru dan siswa ini memiliki masukan positif bagai guru untuk meningkatkan keaktifan siswa dalam berinteraksi dan mewujudkan pembelajaran lebih 
kondusif. Oleh sebab itu, Bagi guru diharapkan memperhatikan prinsip kerjasama dalam memberikan penjelasan kepada siswa atas materi yang dipelajari.

Selain itu, hasil penelitian ini memberikan masukan berharga pada peneliti selanjutnya untuk memperluas kajian penelitiannya untuk memberikan solusi alternatif dalam meningkatkan keterlibatan aktif siswa dalam pembelajaran yakni dengan penelitian bertema pematuhan maksim relevansi dan maksim pelaksanaan dalam pembelajaran Bahasa Arab.

\section{Daftar Pustaka}

Adebola, Otemuyiwa Abosede. "Cooperative Principle Maxims In Whatsapp Conversations Among Undergraduates In The Federal University of Technology Akure, Ondo State, Nigeria." Advances in Social Sciences Research Journal 5, no. 10 (2018): 542-57. https://doi.org/10.14738/assrj.510.5309.

Ashsiddiqi, M Hasbi. "Kompetensi Sosial Guru Dalam Pembelajaran Dan Pengembangannya." Ta'dib XVII, no. 14 (2012): 61-67.

Asmadawati. "Perencanaan Pengajaran." Jurnal Darul 'Ilmi 02, no. 01 (2014): 1-13.

Asyifa Ulam, Emzir, Nuruddin. "Analisis Linguistik Prinsip Kerjasama Dalam

Tuturan Cerita Humor Nawadir Juha Li Al-Athfal." Arabi: Journal of Arabic

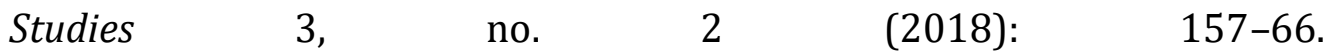
https://doi.org/http://dx.doi.org/10.24865/ajas.v3i2.84 ANALISIS.

Ayu, Gusti, Ketut Utami, Ulan Dewi, I Wayan Widiana, and I Ketut Dibia. "Analisis Interaksi Guru Dan Siswa Dalam Pembelajaran Bahasa Indonesia Di Kelas 1 SDN 1 Nawakerti." E Journal PGSD Universitas Pendidikan Ganesha 4, no. 1 (2016): 1-10.

Hanifah, Umi, and Muhfidatul Winda Winda Hidayah. "Tathbîq Wasîlah AlTa'Lim 'Powtoon' Fî Tarqiyyati Mahōrah Al-Qirō'Ah." Al Mi'yar: Jurnal Ilmiah Pembelajaran Bahasa Arab Dan Kebahasaaraban 4, no. 1 (2021): 1. https://doi.org/10.35931/am.v4i1.362. 
Hikmah, Nurul. "Pembelajaran Kalam Dengan Media Musik (Lagu)." Al Mi'yar: Jurnal Ilmiah Pembelajaran Bahasa Arab Dan Kebahasaaraban 2, no. 1 (2019): 1. https://doi.org/10.35931/am.v2i1.98.

I Made Rai Arta. "Prinsip Kerjasama Dan Kesantunan Pada Pembelajaran Bahasa Indonesia Dengan Pendekatan Saintifik." Palapa: Jurnal Studi Keislaman Dan Ilmu Pendidikan 4, no. 2 (2016): 139-51.

Inah, Ety Nur. "Peran Komunikasi Dalam Interaksi Guru Dan Siswa." Jurnal AlTa'dib 8, no. 2 (n.d.): 150-67.

Iqbal, Muhammad. "Penggunaan Metode Mim- Mem Untuk Mengembangkan Keterampilan Berbicara." Al Mi'yar: Jurnal Ilmiah Pembelajaran Bahasa Arab Dan Kebahasaaraban 1, no. 2 (2018): 113. https://doi.org/10.35931/am.v1i2.48.

Kelik Wachyudi, Mansyur Srisudarso, Fauzi Miftakh. "Analisis Pengelolaan Dan Interaksi Kelas Dalam Pengajaran Bahasa Inggris." Jurnal Ilmiah Solusi 1, no. 4 (n.d.): 40-49.

Nazihah, Wafiqotin, and Gigit Mujianto. "Maksim Kuantitas Pada Ragam Kolokial Dalam Sentra Pelayanan Publik." Alinea: Jurnal Bahasa, Sastra, Dan Pengajaran 9, no. 2 (2020): 85. https://doi.org/10.35194/alinea.v9i2.951.

Pan, Weiwei. "Linguistic Basis of Humor in Uses of Grice's Cooperative Principle." International Journal of Applied Linguistics and English $\begin{array}{lllll}\text { Literature } \quad 1, \quad \text { no. } & 6 & \text { 2012): }\end{array}$ https://doi.org/10.7575/ijalel.v.1n.6p.20.

Payuyasa, I Nyoman, Prof I Made Sutama, M Pd, Prof Ida, Bagus Putrayasa, and M Pd. “Guru Dan Siswa Dalam Pembelajaran Bahasa Dan Sastra Indonesia Di Kelas Xi Sma Negeri 1 Blahbatuh Students Speech Acts in Learning Indonesian Language and Literature In" 3, no. 3 (2014).

Prasetio Rumondor, Ridwan Nur Sineke. "Pola Interaksi Guru PAI Dengan Siswa Dalam Meningkatkan Hasil Belajar Di SMA Negeri 1 Belang." AlHikmah: Jurnal Pendidikan Dan Pendidikan Agama Islam 2, no. 2 (2020): 160-72.

Qassemi, Mohsen, Roya Sedigh Ziabari, and Iran Reza Kheirabadi. "Grice\&quot;s Cooperative Principles in News Reports of Tehran Times-A Descriptive-Analytical Study." International Journal of English Language \& 
Translation Studies, 2013, 66-74. www.eltsjournal.org.

Rahmawati, Anggun, and C Indah Nartani. "Kompetensi Sosial Guru Dalam

Berkomunikasi Secara Efektif Dengan Siswa Melalui Kegiatan Pembelajaran Bahasa Indonesia Di SD Negeri Rejowinangun 3 Kotagede Yogyakarta." Trihayu: Jurnal Pendidikan Ke-SD-An 4, no. 3 (n.d.): 388-92.

Ristiawan, H. "Prinsip Kerja Sama Dalam Berinteraksi Di Lingkungan SMPN 11

Kota Jambi." Pena 7, no. 2 (2017): 99-116. https://onlinejournal.unja.ac.id/pena/article/view/4768.

Sari, Ni Wayan Eminda. "Pelaksanaan Prinsip Kerja Sama Dalam Percakapan

Guru Dan Siswa Serta Dampaknya Terhadap Pembelajaran Bahasa Indonesia Di Kelas Xi Sman I Kediri." Jurnal Santiaji Pendidikan (JSP) 3, no. 2 (2013): 178-88. https://doi.org/10.36733/jsp.v3i2.493.

Sebtiana, Yayuk. "Tuturan Lokusi, Ilokusi, Dan Perlokusi Dalam Interaksi Pembelajaran Siswa Kelas VII Di SMP Negeri 2 Jumapolo." Universitas Muhammadiyah Surakarta. Universitas Muhammadiyah Surakarta, 2018.

Syafri, S I. "Penggunaan Maksim Kuantitas Dan Kualitas Dalam Proses

Pembelajaran Bahasa Indonesia Siswa Kelas Ix Smpn 3 Wonomulyo." Core.Ac.Uk, 2018. https://core.ac.uk/download/pdf/185622835.pdf.

Tiani, Riris. "Penyimpangan Maksim Kualitas Dan Kuantitas Dalam Humor Sutra ' Di Tabloid Mantra." In Seminar Nasional Prasasti (Pragmatik: Sastra Dan Linguistik), 173-79, 2017.

Ulfah, S. Musyafir. "Analisis Tindak Tutur Perlokusi Pada Kumpulan Cerpen 'Bibir' Karya Bakdi Soemanto." Kreatif 18, no. 1 (1995): 24-33.

Yoga, Evita Sholeha Pra. "Tindak Perlokusi Dalam Percakapan Antarsiswa Kelas VII SMP Muhammadiyah Ahmad Dahlan Metro Tahun Pelajaran 2016/2017." Universitas Lampung, 2017. 